June 1990

\title{
Dr. Freud vs. Dr. Spock
}

Timothy C. Smith, M.D.

Thomas Jefferson University

Follow this and additional works at: https://jdc.jefferson.edu/jeffjpsychiatry

Part of the Psychiatry Commons

Let us know how access to this document benefits you

\section{Recommended Citation}

Smith, M.D., Timothy C. (1990) "Dr. Freud vs. Dr. Spock," Jefferson Journal of Psychiatry. Vol. 8 : Iss. 2 , Article 12.

DOI: https://doi.org/10.29046/JJP.008.2.011

Available at: https://jdc.jefferson.edu/jeffjpsychiatry/vol8/iss2/12

This Article is brought to you for free and open access by the Jefferson Digital Commons. The Jefferson Digital Commons is a service of Thomas Jefferson University's Center for Teaching and Learning (CTL). The Commons is a showcase for Jefferson books and journals, peer-reviewed scholarly publications, unique historical collections from the University archives, and teaching tools. The Jefferson Digital Commons allows researchers and interested readers anywhere in the world to learn about and keep up to date with Jefferson scholarship. This article has been accepted for inclusion in Jefferson Journal of Psychiatry by an authorized administrator of the Jefferson Digital Commons. For more information, please contact: JeffersonDigitalCommons@jefferson.edu. 


\title{
Book Reviews
}

\section{Dr. Freud vs. Dr. Spock}

\author{
CHILDREN OF PSYCHIATRISTS AND OTHER PSYCHOTHERAPISTS \\ Thomas Maeder \\ Harper and Row publishers, New York \\ 1989, 259 pages, $\$ 19.95$
}

Timothy C. Smith, M.D.

Thomas Maeder's "Children of Psychiatrists and other Psychotherapists" seeks to answer the question: “Are shrinks' kids nuts?" To study this topic, Maeder, the son of a psychiatrist-psychoanalyst and a psychiatric social worker, interviewed over two hundred children of psychotherapists and a number of child psychiatrists. He portrays children of psychotherapists as emotionally vacant, unhappy, analytical, and under constant analysis by their parents. He concludes that being raised by psychotherapist-parents has adversely affected these children. Maeder presents psychotherapists as inept parents who themselves are emotionally impaired, come from unhappy childhoods, or have "God complexes." While an interesting theory, it is undermined by the resentful tone of the author's writing.

As the son of a psychiatrist I can say that Mr. Maeder's book contains a few familiarities. My upbringing, however, seems to have been fundamentally different from that of the author and those interviewed. While psychotherapy and psychology seem to have pervaded much of Maeder's and the interviewees' childhoods, my fathers profession rarely took precedence over daily occurrences, discussions of current events, sports, etc. I found little, if anything, in common with many of the supposedly typical experiences Maeder documents. For example, a daughter's question as to why her father is angry is met with the reply, "I'm not angry, you're just projecting." This kind of interaction did not occur in my home. I believe that in trying to support his theories Maeder focuses on the sensational; the end result shares little with my life's experiences.

The book suffers from other shortcomings. Maeder continually states his beliefs as fact despite their lack of statistical basis. I believe the bias of this book is largely due to the finding of interviewees by word of mouth and through friends and aquaintances - a process the author calls "randomization." Although Maeder states in his introduction that not all children of psychiatrists are impaired the entire book focuses on this topic. Moreover, Maeder appears biased; he assumes 
that psychotherapists are damaged and that children of therapists are "crazy" and sets out to prove these "facts." In only one sentence does Maeder entertain the idea that the assumptions mentioned above may reflect a society with a high degree of discomfort concerning emotions and feelings.

The book is not without merit. Maeder explains well what psychotherapists are, what they do, as well as some aspects of their training. He puts forth a strong point that psychotherapy is a treatment for patients and has a questionable, if any, role in child rearing. Most importantly, this book touches on a relatively unstudied area. There is only one entry on this topic in the Psychlit literature indexing system (which indexes back to 1976).

Thomas Maeder's "Children of Psychiatrists and other Psychotherapists" is a most difficult book. His assumption that psychotherapists are impaired and that therapists kids are "crazy" implies many of the stigmata that psychiatry eschews. Maeders' style reads like a letter being sent from an angry child to his parents. The message of this letter could best be summarized in the following passage: "It is easier to find one's way in the world when one knows the real importance of things, has made mistakes and learned from experience, and had a normal dose of life's hard knocks." At no time was I able to read twenty pages without feeling that the author has an axe to grind with his parents. I agree with Maeder that psychotherapy should not be done on "healthy" children. Unfortunately Maeder's delivery of his conclusions is more like Lizzy Borden's than that of an unbiased researcher. 